\title{
The Value of Natural History
}

OF ALL THE JOYS of life which may fairly come under the head of recreation there is nothing that surpasses Natural History. It opens up a world of interest and beauty whose cultivation brings physical, intellectual and aesthetic satisfactions.

Since natural history is pursued out of doors it satisfies the need for healthful physical exercise and at relatively small cost. There is no end to the intellectual interest provided by an interest in birds, plants, trees, and other features of the natural world.

Nothing is more refreshing or more satisfying to our aesthetic natures than a love of the beauty of the world. Speaking of this, Viscount Grey of Falloden, Foreign Secretary of Great Britain during the First Great War, wrote "It was like a great sanctuary into which we could go and find refuge for a time from even the greatest trouble of the world, finding there not enervating ease, but something which gave optimism, confidence and security. The progress of the seasons unchecked, the continuance of the beauty of nature was a manifestation of something great and splendid which not all the crimes and follies and misfortunes of mankind can abolish or destroy." -The Federation of Ontario Naturalists

search and careful observation; the more intelligently we shall be able to manage these grand resources. ... To ensure that our children and those to follow can enjoy them to an even greater extent than .we do today. Wildlife needs water, food and cover. ... If we see to it that these basic requirements are safeguarded, added to or provided, we cannot go far wrong.

Who is responsible for wildlife? Some people say, "Let Mother Nature look after her own." ... Others retort, "Up to the government." . . . Actually, recorded history reveals that Mother Nature isn't quite a match for man-made pressures on wildlife populations. ... And government is you, so who is responsible?

\section{Nature's Balanced Equation}

\section{By John Clayson}

\section{(From "The Wood Duck")}

A dirt side road travelled at twenty to twenty-five miles per hour with the driver gawking to right and left does not get you anywhere very fast. It may kick up a little dust behind you, but the varied countryside around you kicks up a very different kind of dust inside you. By alchemy quiet rolling farmland on your left, plus the gentian blue of Lake On- tario on your right, plus the sounds of animal life all around you, catalyzed by the influence of warm afternoon sunlight at your back, reacts to yield calm yet zestful tranquility as you putter along. Early morning or late afternoon colour, as you come over the crest of a hill gives you a "long" look that is a continuing source of pleasure. On the water, glittering sequins from a shaft. of early morning sunlight, breaking through unwashed woolly clouds, can produce a brightness within.

\section{GIVE WILDLIFE A BRAKE}

Thousands of animal casualties on highways could be avoided this summer if motorists would apply a little brake pressure and toot their horns, the National Audubon Society declares. Blinking of headlights at night will often disperse animals that otherwise are transfixed by a steady beam. A considerate driver is a boon to humans and wildlife alike.

Research indicates that a Blue Goose gosling increases its birthweight by 16 to 20 times during its first two months of life ... At this rate of growth, an average human infant would weigh between 130 and 160 pounds when seven or eight weeks old. 